\title{
MODEL PEMBELAJARAN SENTRA DAPAT MENGEMBANGKAN SIKAP BERSOSIAL UNTUK ANAK USIA TAMAN KANAK KANAK
}

\author{
Achmadi \\ Program Studi PGPAUD FKIP Universitas PGRI Adi Buana Surabaya \\ e-mail: achmadi@unipasby.ac.id
}

\begin{abstract}
Early childhood is the development of all aspects of life both in physical and psychological aspects. One of them is social and emotional development.. The background in this research is to study the development of social and emotional aspects of children through center learning models. The fact that the Center learning model is to provide the opportunities students for societal and good behavior. Besides that, the Center learning model is centered for the children. The children are given the freedom to choose their friends and to carry out for the types of assignments are given by their teachers.Through the Center learning model will perform good social and emotional behavior. In addition, the BCCT learning model or Center model comes down to the chilhood's achievement in theall aspects' human development. Therefore, this learning model should be planned carefully through the various tool's playing (playing activities) to facilitate the achievement of the children's development. The goal of the research is to know the development of the social's child and emotional attitudes through the Center learning model. Type of this research is quantitative research two group design. The subjects research by using the children as many as 24 children are divided two groups. 12 children are as the control group, and 12 children as the experimental group. For analysis data by using the different velue between the control group and the experimental group. The result is the probability of sig is 0.178 and the significant in $5 \%$ is 0.025 . The conclusion in this research iis The Center learning model can not form the societal and emotional.behavior for early childhood in TK Sunan Cendono Kecamatan Kwanyar Kabupaten Bangkalan.
\end{abstract}

Keywords: Center Learning Model, Social and Emotional Behavior

\section{PENDAHULUAN}

Pada masa berkembangnya anak usia 3 sampai 6 tahun banyak terjadi permasalahan yang dirasakan dan dialami oleh orang tua. Misalnya anak mudah rewel tanpa alasan, tidak mau bermain dengan anak lain. Anak mudah marah bila ditinggal sebentar oleh orang tuanya khususnya oleh Ibunya. Anak selalu merasa tidak cocok bila diarahkan untuk memilih alat permainan atau barang-barang lainnya. Sifat seperti selalu dialami oleh anak usia dini. Hal ini sesuai pendapat Montesori (dalam Susanto 2011:133) “Anak usia dini sebagai periode sensitif (sensitive periods). Anak mengalami kesulitan dalam bersosial dan mengoreksi emosionalnya. Bila bersosial selalu terjadi permasalahan dengan temannya. Bentuknya bisa berupa menangis, bertengkar, dan tidak mau berkontak sosial. Disamping itu anak juka mudah bersikap yang kurang baik, misalnya marah-marah , berucap kotor, tidak sopan, suka mencibir, menghina atau membuli, dan lain sebagainya. Permasalahan ini perlu diatasi oleh guru kelas maupun orang tua. Salah satu bentuk pengatasannya oleh guru kelas dapat dilakukan melalui penggunaan model pembelajaran, yaitu dengan model sentra. Menurut dinas pendidikan kota Malang (dalam Masruroh 2014:45), metode sentra adalah pendekatan penyelenggaraan Pendidikan Anak Usia Dini yang berpusat pada anak yang dalam proses pembelajarannya, berpusat di sentra main dengan menggunakan minimal 4 pijakan 
(kegiatan bermain) untuk mendukung perkembanagan anak.Langkah kegiatannya berupa penjelasan sebelumbermain, kegiatan selama bermain, dan kegiatan setelah main. Dengan model sentra guru harus bisa memahami situasi dan kondisi masing-masing anak. Pendapat Montesori (Susanto 2011:131) menyatakan bahwa memahami kemampuan dan kecakapan anak itu sangat diperlukan. Guru dan orang tua dikatakan gagal memberi pelayanan kepada anak usia dini karena tidak dapat memahami bahwa masing-masing anak itu mempunyai kecerdasan dan kemampuan belajar yang berbeda-beda. Tidak bisa disamakan antara anak satu dengan anak lainnya.

Berdasar dari uraian diatas, maka rumusan masalahnya adalah : Model pembelajaran sentra dapat mengembangkan sikap bersosial untuk anak usia Taman Kanak Kanak. Sedangkan tujuannya untuk mengetahui pengaruh model pembelajaran sentra terhadap perkembangan sikap sosial dan emosional pada anak usia dini.

Metode penelitian yang digunakan adalah metode penelitian kuantitatif dengan menggunakan pendekatan non parametris. Penelitian ini dilaksanakan di TK Sunan Cendono Kecamatan Kwanyar Kabupaten Bangkalan, Madura. Hasil penelitian menunjukkan bahwa model pembelajaran sentratidak ada berpengaruhnya terhadap pengembangan sikap sosial dan emosional anal TK Sunan Cendono Kecamatan Kwanyar Kabupaten Bangkalan, Madura

\section{METODE PENELITIAN}

Penulis menggunakan penelitian kuantitatif dengan menggunakan pendekatan non parametris, sebab dalam penelitian ini penulis bebas menggunakan penyebaran dan tidak membatasi dan tidak mensyaratkan bentuk sebaran parameter populasinya baik secara normal maupun tidak normal.

Desain Penelitiannya dapat digambarkan sebagaiberikut (Sugiyono, 2014:76)

$\begin{array}{lll}\text { R1 } & \mathrm{X} & \mathrm{O}_{2} \\ \mathrm{R} 3 & & \mathrm{O}_{4}\end{array}$

Keterangan :

R 1= Kelompok Eksperimen

$\mathrm{X}=$ Tindakan/Perlakuan untuk kelas experimen

$\mathrm{O}_{2}=$ Posttest kelas experimen

R 3= Kelompok Kontrol

$\mathrm{O}_{4}=$ Posttest kelas kontrol

Penelitian ini dilaksanakan pada anak kelompok A di TK Sunan Cendono Kecamatan Kwanyar Kabupaten Madura tahun ajaran 2017/2018 dengan jumlah populasinya sebanyak 24 anak. Adapun lama penelitian selama 3 minggu, Metode pengumpul data penulis menggunakan observasi Menurut Sugiyono, dalam Dimyati (2013 : 70) pengumpulan data yaitu berkenaan dengan cara - cara yang digunakan dalam mengumpulkan data. Diantaranya dapat dilakukan dengan tes dan non tes. Jenis non tes antara lain interview ( wawancara), kuesioner (angket), observasi ( pengamatan), dan lain sebagainya. Jenis pengumpul data dalam penelitian ini yaitu , observasi. Menurut Morrison (2008:164) observasi adalah alat "autentik"saat pembelajaran tentang apa - apa yang mereka ketahui dan mampu lakukan, terutama saat pembelajaran terjadi dilingkungan yang alamiah seperti di kelas, di pusat perawatan anak, tempat bermain, dan di rumah. Metode ini adalah salah satu metode yang paling banyak digunakan untuk menilai suatu kegiatan anak usia dini. Observasi ini dilakukan kepada anak 
untuk mengumpulkan data dalam mengamati perilaku sosial emosional anak saat pembelajaran model sentra dengan indikator yang telah digunakan dan kriteria yang telah ditentukan. Indikator dalam penelitian ini adalah anak mau bekerjasama dengan teman-temannya dan mau berbagi saat melakukan kegiatan sentra.

\section{HASIL PENELITIAN}

Sebelum pembahasan secara detail, penulis sajikan hasil nilai kuantitatif untuk kelompok kontrol dan kelompok eksperimen

\section{Tabel 4.1}

Nilai kelompok kontrol dan eksperimen

\begin{tabular}{rcc}
\hline No. & Kelp. Kontrol & kelp. Eksperimen \\
\hline 1 & 2.0 & 3.0 \\
2 & 3.3 & 4.0 \\
3 & 3.3 & 4.0 \\
4 & 2.3 & 4.0 \\
5 & 1.3 & 3.0 \\
6 & 1.6 & 3.7 \\
7 & 2.6 & 3.0 \\
8 & 2.6 & 4.0 \\
9 & 3.6 & 4.0 \\
10 & 2.0 & 3.3 \\
11 & 2.3 & 3.0 \\
12 & 3.0 & 3.0 \\
\hline
\end{tabular}

Tabel tersebut selanjutnya dianalisa dengan bantuan SPSS. Adapun hasilnya adalah:

Kelas kontrol berjumlah 12 anak dan Kelas eksperimen juga berjumlah 12 anak. Hasil analisa dari tabel independen sampel tes menunjukkan probabilitas $(\mathrm{sig})=0.178$. Sedangkan nilai taraf signifikan $0.05 / 2=0.025$.

Sesuai rumus pengambilan keputusan berdasarkan nilai probabilitas : Jika probailitas (sig) $>0.025$ maka Ho diterima . Jika probailitas (sig) $<0.025$ maka Ho ditolak.

Dengan demikian dapat disimpulkan Nilai probabilitas $(\mathrm{sig})=0.178$ lebih besar dari nilai taraf signifikansi $=0.025$, maka Ho diterima. Untuk itu rumusan hipotesa dalam penelitian ini yang berbunyi model pembelajaran sentra tidak bisa membentuk perilaku anak dalam bersosial maupun emosional di TK Sunan Cendono Kecamatan Kwanyar Kabupaten Bangkalan, Madura diterima.

\section{PEMBAHASAN}

Model pembelajaran klasikal merupakan model pembelajaran yang berpusat pada guru sehingga bentuk dan aturannya lebih di dominasi oleh guru.Semua kegiatan pembelajaran berlangsung selalu ditentukan oleh guru, sehingga minat dan jalannya permainan anak dilakukan secara terikat. Secara tidak langsung perilaku bersosial dan emosional anak tidak berkembang secara optimal.

Untuk mengoptimalkan tercapainya tujuan pendidikan pada anak usia dini diperlukan model pembelajaran yang tepat. Oleh karena itu guru perlu menyiapkan suatu model pembelajaran yang sesuai dengan dunia anak. Ketepatan dan kesesuaian penggunaan model pembelajaran ini sangat penting karena bisa berdampak signifikan terhadap cara dan proses pembelajaran anak selanjutnya. Model pembelajaran yang tepat dan sesuai dengan dunia anak dapat memfasilitasi perkembangan berbagai potensi dan kemampuan anak secara optimal serta tumbuhnya sikap dan perilaku positif yang mendukung pengembangan 
berbagai potensi dan kemampuan anak tersebut.

Model pembelajaran BCCT atau pembelajaran berbasis sentra adalah sebuah model pembelajaran yang menjadikan bermain sebagai wahana belajar anak. Adapun penerapannya mendasarkan asumsi, bahwa benda-benda dan orang-orang disekitarnya (lingkungan) itu sebagai alat belajarnya anak usia dini .Halimah (2011:13).

Sedangkan menurut Mulyasa (2014) pembelajaran berbasis sentra adalah model pembelajaran yang dilakukan didalam "lingkaran" (circle times) dan sentra bermain. Lingkaran adalah saat ketika guru duduk bersama anak dengan posisi melingkar untuk memberikan informasi tentang pijakan kepada anak yang dilakukan sebelum dan sesudah bermain. Sentra bermain adalah zona atau area bermain anak yang dilengkapi dengan seperangkat alat bermain, yang berfungsi sebagai pijakan lingkungan yang diperlukan untuk mengembangkan seluruh potensi dasar anak didik dalam berbagai aspek perkembangannya secara seimbang.

Model pembelajaran Sentra atau BCCT bertujuan untuk merangsang seluruh aspek kecerdasan anak, salah satunya kecerdasan sosial emosional anak. Model Pembelajaran Sentra memperkaya pengalaman bermain anak, merangsang kemampuan sosial dan emosional pada anak usia dini dan berpengaruh positif pada perkembangan intelektual anak. Pada model pembelajaran Sentra atau BCCT wujudnya berupa proses bermain sambil belajar, anak-anak diberikan kesempatan untuk berinteraksi dengan teman sebayanya tanpa keterlibatan guru. Adanya interaksi antar anak maka dapat berpengaruh terhadap kemampuan anak dalam bersosialisasi.

Berdasarkan penjelasan tersebut di atas serta prinsip-prinsip pembelajaran Sentra yang tertulis antara lain:

a. Anak belajar dibeberapa sentra secara bergiliran.

b. Kegiatan apersepsi dan penutup dilaksanakan dengan cara anak dan guru duduk bersama di lingkaran besar.

c. Kegiatan inti dilakukan di sentra-sentra.

d. Memperhatikan jumlah waktu yang dibutuhkan anak untuk pengalaman dalam bermain (intensitas bermain).

e. Memperhatikan berbagai macam cara jenis main yang disediakan untuk mendukung pengalaman anak (densitas).

Maka hasil penelitiannya tidak sesuai dengan prinsip dan model Sentra.

Dari hasil analisis di lapangan tentang penggunaan model pembelajaran baik secara klasikal (kelompok kontrol) dan kelas eksperimen di TK Sunan Cendono Kecamatan Kwanyar Kabupaten Bangkalan masih belum sesuai dengan prinsip-prinsip pembelajaran Sentra. Dapat diketahui bahwa perilaku sosial emosional anak belum berkembang dengan baik. Biarpun untuk kelas eksperimen telah diberikan perlakuan menggunakan model pembelajaran BCCT atau sentra selama tujuh 
kali perlakuan. Perilaku sosial emosional anak belum bisa berkembang secara maksimal karena model pembelajaran BCCT atau Sentra kurang menarik minat anak. Seharusnya dengan adanya berbagai macam jenis permainan dan kegiatan yang disediakan guru, anak dapat memilih sesuai dengan keinginan dan prioritasnya. Disamping itu alat-alat itu juga dapat memberikan kesempatan kepada anak untuk bereksplorasi serta dapat berinteraksi dengan teman sebayanya tanpa keterlibatan guru. Tetapi hasilnya tidak ada interaksi yang optimal antar anak secara sukarela. Mereka senang main sendiri-sendiri. Alat yang dipakai hanya satu jenis mainan saja. Mereka juga tidak optimal dalam melibatkan teman-temannya dalam bermain bersama. Saran dan petunjuk guru tidak banyak diperhatikan. Proses dan langkah-langkah pembelajaran sentra tidak difahami anak. Biarpun guru sudah berkali-kali menginformasikan dan menunjukkan jalannya bermain disentra. Pada umumnya anak-anak tidak bisa memperhatikan waktu atau durasi bermain. Selama anak senang bermain dengan 1 jenis mainan atau 1 jenis alat permainan, mereka sampai akhir kegiatan hanya bermain itu saja. Biarpun guru juga sudah mengarahkan kepada anak untuk saatnya ganti mainan. Dengan kondisi semacam ini proses pembelajaran sentra di TK ini tidak sesuai dengan prinsip-prinsip model pembelajaran Sentra atau BCCT. Berarti hasil pembahasannya adalah pemberian alat permainan kepada anak tidak dapat meningkatkan kemampuan anak dalam berperilaku sosial dan emosionalnya.

\section{SIMPULAN DAN SARAN}

\subsection{Simpulan}

Bahwa tidak ada pengaruh model pembelajaran BCCT atau sentra terhadap perilaku sosial emosional anak kelompok A di TK Sunan Cendono Kecamatan Kwanyar Kabupaten Bangkalan Madura

\subsection{Saran}

a. Saran ini ditujukan kepada semua unsur tenaga terkait dalam dunia pendidikan bahwa mempelajari dan memahami model pembelajaran sentra (BCCT) sangat mutlak diperlukan, sebab sifat anak yang unik dan memiliki kesenangan bermain, berkumpul sebaya, berimajinatif sangat cocok dikelola secara terbuka bebas, bukan secara klasikal.

b.Saran ditujukan kepada peneliti atau calon peneliti ke-paud-an bahwa model pembelajaran sentra bagi anak usia dini dapat digunakan untuk mengetahui ada atau tidaknya pengaruh terhadap semua aspek perkembangan anak.

c. Saran untuk Tim pembuat kebijakan pendidikan anak usia dini bahwa model pembelajaran sentra untuk anak usia dini merupakan model pembelajaran yang saat ini sangat tepat dan cocok digunakan di lembaga PAUD. Untuk itu dapat dikeluarkan suatu kebijakan agar semua guru PAUD dapat memahami dan dapat mengaplikasikannya di lapangan.

\section{PERNYATAAN TERIMA KASIH (jika}

\section{diperlukan)}


Ucapan terimakasih disampaikan kepada Kepala Sekolah TK Sunan Cendono Kecamatan Kwanyar Kabupaten Bangkalan atas pemberian kesempatan kepada penulis dalam melaksanakan penelitian.

Ucapan terimakasih juga disampaikan kepada semua Dosen PG-PAUD Universitas PGRI Adi Buana Surabaya yang telah memberikan ilmu, wawasan serta bimbingannya dalam menyelesaikan pembuatan karya ilmiah dalam bidang kePAUD-an

\section{REFERENSI}

Arikunto Suharsimi. (2013). Prosedur Penelitian.Jakarta : Rineka Cipta Dimyati Johni.(2013). Metodologi Penelitian Pendidikan dan Aplikasinya.Jakarta: Kencana.

Depdiknas. (2006). Pedoman Penerapan pendekatan Beyond Center and Circle Time (BCCT) Pendekatan Sentra dan Lingkaran Pendidikan Anak Usia Dini. Haenilah. (2015). Kurikulum dan Pembelajaran PAUD.Yogyakarta: Media Akademi

Masruroh Ninik. (2014). Manajeman Inovasi Pembelajaran.Jakarta: Mitra Wacana Media.

Sugiyono. (2016). Prosedur Penelitian. Bandung: Alfabeta.

Susanto Ahmad. (2011). Perkembangan Anak Usia Dini 